\title{
豚の産肉、肉質及び生理的形質間の遺伝的関連
}

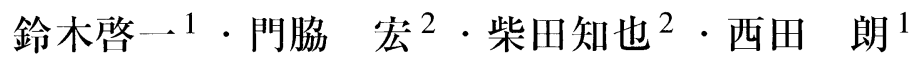 \\ 1 東北大学大学院農学研究科資源生物科学専攻動物遺伝育種学分野、2 宮城県畜産試験場種豚家きん部
}

\section{Genetic correlation between meat production traits, meat quality traits and physiological traits in pigs}

\author{
Keiichi SUZUKI ${ }^{1}$, Hiroshi KADOWAKI ${ }^{2}$, Tomoya SHIBATA ${ }^{2}$ and Akira NISHIDA ${ }^{1}$ \\ ${ }^{1}$ Department of Animal Genetics and Breeding, Graduate School of Agricultural Science, Tohoku University \\ 2 Miyagi Prefecture Animal Industry Experiment Station
}

\section{1. はじめに}

近年、豚における選抜目標は産肉形質から肉質形質 へと変化してきており、食味に関連した研究が報告さ れている (Cameron 1993; Hovenier ら 1993)。わが国 では豚肉は主に精肉の消費が多い。精肉の場合、軟ら かさ、保水性が食味に影響する重要な形質と思われる。 加えて、筋肉内脂肪は食味性と口の中での肉のなめら かさに関連して重要な形質である。日本人はしもふり の牛肉と同様に豚肉でも筋肉内脂肪の入った肉に強い 興味を持っている。筋肉内脂肪に関する遺伝率は中程 度であることが報告 (Sellier 1998 の総説)されている が、生きている豚で肉質を測定することは困難である。 肉質に関連する測定は経費と多くの時間を要する。こ のため、筋肉内脂肪を直接の選抜形質とした事例は TOKYO-Xを除いてない。宮城県畜産試験場では、 1995 年にデユロック豚の産肉形質と肉質形質を選抜形 質とした 7 世代の選抜試験を開始し、2001 年に終了し た。この選抜試験の目的は、豚の品種の中でも筋肉内 脂肪含量の高いデユロック種において、産肉形質と筋 肉内脂肪の両方を選抜形質とした改良が可能かどうか を検討することであった。試験では、7世代で育成雄、 育成雌と調查豚の合計 1,643 頭の産肉能力検定を行い このうち、543頭の調查豚について、筋肉内脂肪を含 む様々な肉質形質を測定した。そこで、以下に述べた 課題を設け他の研究機関との協力により肉質形質、生 理的形質の詳しい分析を行った。

本稿では、直接選抜反応、肉質形質の遺伝的パラ メー夕と相関反応、脂肪組織の脂肪酸組成と融点に関 する遺伝的パラメー夕と相関反応、生理的指標として の血中 IGF-1、レプチン濃度と産肉、肉質形質間の遺 伝的関連と相関反応、筋肉内脂肪と Seam fat score（口
一ス周辺の筋肉間脂肪蓄積スコア) や枝肉全体の脂肪 蓄積との遺伝的関連について紹介する。最期に今後の 課題を付け加えた。

\section{2. 産肉、肉質形質を選抜形質としたデユロック豚の 選抜試験}

選抜試験を行うに当たり基礎集団を導入したが、特 徵は産肉能力に優れた雄豚を精液として海外から導入 したことである。雄豚 23 頭のうち、生豚は 2 頭だけ であり残りは凍結と液状精液で導入した。また、雌豚 は県外、県内から広く合計 49 頭導入した。選抜試験 の基本計画は系統造成の一般的なスタイルとしたが、 能力検定は体重が $30 \mathrm{~kg}$ から $105 \mathrm{~kg}$ までとした。また、 肉質調查のため、一腹から 2 頭の調查豚 (去勢を主体 とした）を設け、毎世代 80 頭前後の調査豚の肉質を分 析した。選抜形質は一日平均增体量、ロース断面積、 背脂肪厚と筋肉内脂肪の 4 形質とし、第一世代の検定 成績から希望改良量を設定した。また、相関形質とし て肉の柔らかさ（TENDERNESS）を測定し、第一世代 の記録の $78 \mathrm{~kg} \mathrm{f} / \mathrm{cm}^{2}$ をできるだけ低め、肉を軟らかく することを検討した。選抜方法は第 1,2 世代では選 抜指数法により行った。改良目標量と遺伝的パラメー 夕により選抜指数式を作成した。第 3 世代以降は PEST プログラム (PEST 1990) により BLUP 法アニマ ルモデルにより育種価を計算し、個体ごとに総合育種 価を計算した。なお、相対的重要度は改良目標量から 逆算して計算した。また、遺伝的パラメー夕の推定は VCE4.25（Neumaier と Groeneveld 1998）を使い、世代と 性を母数効果、相加的遺伝的効果と共通環境効果を变 量としたアニマルモデル REML法により推定した。

表 1 には全世代の個体を含めて計算した遺伝率推定 
表 1. 選抜形質及び相関形質の基本統計量と遺伝率 $\left(\mathbf{h}^{2}\right) \pm$ 標準誤差 $(\mathbf{S E})$ 、共通環境効果 $\left(\mathbf{c}^{2}\right) \pm$ 標準誤差 $(\mathbf{S E})$ および表型標準偏差 $\left(\sigma_{\mathbf{p}}\right)$

\begin{tabular}{lcccccc}
\hline \multicolumn{1}{c}{ 形 質 } & $\mathrm{N}$ & $\mathrm{Mean}$ & $\mathrm{SD}$ & $\mathrm{h}^{2} \pm \mathrm{SE}$ & $\mathrm{c}^{2} \pm \mathrm{SE}$ & $\sigma_{\mathrm{p}}$ \\
\hline 1 日平均増体量, $\mathrm{g} / \mathrm{day}$ & 1,642 & 873.6 & 109.3 & $0.48 \pm 0.02$ & $0.04 \pm 0.01$ & 80.6 \\
ロース断面積, $\mathrm{cm}^{2}$ & 1,639 & 37.00 & 4.05 & $0.45 \pm 0.03$ & $0.02 \pm 0.01$ & 3.71 \\
背脂肪厚, $\mathrm{cm}$ & 1,642 & 2.37 & 0.43 & $0.72 \pm 0.03$ & $0.01 \pm 0.01$ & 0.39 \\
筋肉内脂肪, $\%$ & 543 & 4.25 & 1.46 & $0.46 \pm 0.03$ & $0.06 \pm 0.02$ & 1.40 \\
テンダーネス, $\mathrm{kg} \mathrm{f} / \mathrm{cm}^{2}$ & 544 & 72.51 & 12.71 & $0.45 \pm 0.04$ & $0.06 \pm 0.02$ & 12.6 \\
飼料要求率 & 379 & 2.65 & 0.17 & $0.34 \pm 0.04$ & $0.19 \pm 0.03$ & 0.17 \\
1 日平均飼料摄取量, $\mathrm{kg} /$ day & 379 & 2.62 & 0.23 & $0.52 \pm 0.03$ & $0.06 \pm 0.01$ & 0.24 \\
\hline
\end{tabular}

表2. デユロック豚の遺伝相関と表型相関推定值

\begin{tabular}{cccccccc}
\hline 形質 & & EM & BF & IMF & TEND & FCR & FID \\
\hline $\mathrm{DG}^{\mathrm{a}}$ & $\mathrm{r}_{\mathrm{G}}$ & $-0.09 \pm 0.05$ & $0.34 \pm 0.04$ & $0.23 \pm 0.07$ & $-0.42 \pm 0.07$ & $-0.09 \pm 0.07$ & $0.83 \pm 0.02$ \\
& $\mathrm{r}_{\mathrm{P}}$ & -0.08 & 0.28 & 0.07 & -0.34 & -0.25 & 0.74 \\
$\mathrm{EM}$ & $\mathrm{r}_{\mathrm{G}}$ & & $-0.45 \pm 0.04$ & $-0.24 \pm 0.04$ & $0.28 \pm 0.06$ & $-0.59 \pm 0.07$ & $-0.42 \pm 0.05$ \\
& $\mathrm{r}_{\mathrm{P}}$ & & -0.29 & -0.24 & 0.20 & -0.21 & -0.22 \\
$\mathrm{BF}$ & $\mathrm{r}_{\mathrm{G}}$ & & & $0.24 \pm 0.04$ & $-0.58 \pm 0.04$ & $0.65 \pm 0.07$ & $0.68 \pm 0.03$ \\
& $\mathrm{r}_{\mathrm{P}}$ & & 0.21 & -0.39 & 0.21 & 0.54 \\
$\mathrm{IMF}$ & $\mathrm{r}_{\mathrm{G}}$ & & & $-0.10 \pm 0.05$ & $0.26 \pm 0.07$ & $0.33 \pm 0.06$ \\
& $\mathrm{r}_{\mathrm{P}}$ & & & -0.20 & 0.16 & 0.48 \\
$\mathrm{TEND}$ & $\mathrm{r}_{\mathrm{G}}$ & & & & $-0.36 \pm 0.07$ & $-0.57 \pm 0.06$ \\
& $\mathrm{r}_{\mathrm{P}}$ & & & & -0.07 & -0.36 \\
$\mathrm{FCR}$ & $\mathrm{r}_{\mathrm{G}}$ & & & & & $0.48 \pm 0.06$ \\
& $\mathrm{r}_{\mathrm{P}}$ & & & & & & 0.48 \\
\hline
\end{tabular}

${ }^{\mathrm{a}} \mathrm{DG}, 1$ 日平均増体量 $\mathrm{EM}$, ロース断面積; BF, 背脂肪厚; IMF, 筋肉内脂肪; TEND, テンダーネス; FCR, 飼料要 求率; FID, 1 日平均飼料摂取量.

$\mathrm{r}_{\mathrm{G}}$, 遺伝相関 \pm 標準誤差.

$\mathrm{r}_{\mathrm{P}}$, 表型相関.

值を示した。一日平均増体量 (DG)、ロース断面積 (EM)、筋肉内脂肪 $(\mathrm{IMF})$ に関する遺伝率は中程度か 0.5 前後の值が得られた。背脂肪厚の遺伝率推定值は 高い值が得られた。肉の軟らかさ (TEND) もまた、中 程度の遺伝率が推定された。不断給慨下での産肉形質 に関しては、DGでは 0.31、BFでは 0.49 の平均の遺伝 率推定值が報告されている (Clutter と Brascamp 1998)。 BFに関する Kuhlers らによる最近の報告ではランドレ 一ス種で 0.56 (2001)、デユロック種で 0.58 (2003) の遺 伝率が報告されている。EMに関する遺伝率は 0.47-0.48 の值が報告されている (Sellier 1998；Kuhlers ら 2001)。本研究で得られた推定值は同じ程度だが、 DG B BFではこれまでの報告より高い值だった。さ
らに、筋肉内脂肪 (IMF) に関しては本研究での推定值 0.46 は Hovenier ら (1993) と Sellier (1998)により報告 された值 (平均 0.5 ) と同程度だった。Tenderness は通 常パネルテストやワーナーブラッアーの剪断力価によ り評価され、0.21 から 0.37 の遺伝率が報告されている (Hovenior ら 1993)。Sellier (1998) もまた、パネルテス トでは $0.29(0.18-0.70) 、$ 機械測定では $0.26(0.17-0.46)$ の遺伝率を報告している。本試験ではテンシプレッサ 一を使い 0.46 の中程度の遺伝率が得られ、きょうだい の情報に基づく選抜だが肉の軟らかさの改良が可能で あることが示唆された。

表 2 には選抜形質と相関形質の遺伝相関と表型相関 を示した。産肉形質間の遺伝と表型相関は従来報告さ 
れている值 (Clutter と Brascamp 1998；Lo ら 1992； Kuhlers ら 2001）と同程度の相関だった。DG と IMF と の遺伝相関、表型相関は 0.22 と 0.07 であり、比較的 低い值だった。Loら (1992) はデユロック、ランドレ 一ス種とそれらの交雑豚から 0.27 と 0.06 の遺伝相関 と表型相関を推定している。Hovenierら (1992)もデユ ロック種と大ヨークシャー種について 0.19 と 0.13 の 遺伝相関と表型相関を報告している。これに対し、de Vreis ら (1994) は大ヨークシャー種について -0.05と 0.15 の遺伝相関と表型相関を、Hermesh ら (2000) は大 ヨークシャ種とランドレース種について、IMF と $0-18$ 週の増体量および $18-22$ 週の増体量の間に 0.01 と -0.21 の遺伝相関を報告している。さらに、 Sonesson ら (1998) は背脂肪厚低、増体量高に選抜され た大ヨークシャー種の DG と IMF の間に -0.30 と -0.17 の遺伝相関と表型相関を報告している。これら の報告を整理すると、対象とする品種の違いにより相 関が異なることが示唆された。すなわち、デユロック 種を含む集団では DG と IMF の間の相関は正だが、ラ ンドレース種や大ヨークシャー種についての相関は負 である。ロース断面積と IMF の間の遺伝相関、表型相 関は -0.27 と -0.24 である。Lo ら (1992) はデユロック、 ランドレース種及びそれらの交雑豚で -0.31 と -0.06 の遺伝相関と表型相関、Hovenier ら (1992) はデユロッ ク種とオランダ大ヨークシャー種について筋肉内脂肪 と赤肉割合との -0.44 と -0.31 の遺伝と表型相関、 Sonesson ら (1998) は大ヨークシャー種について赤肉割 合と筋肉内脂肪の間に 0.02 と -0.05 の遺伝と表型相関 を報告している。それゆえ、ロース断面積や赤肉割合 は筋肉内脂肪とは負の遺伝的関連があると結論され
る。皮下脂肪厚と筋肉内脂肪との遺伝と表型相関は本 研究ではいずれも 0.20 の值が得られた。両者の間には 低から中の遺伝と表型相関が報告されている。本研究 ではTEND とDGとの間に負の好ましい遺伝と表型相 関が得られた $(-0.38$ と -0.34$)$ 。一方、TEND と EM と の間では正の好ましくない相関 (0.20 と 0.18)、BFと の間にも負の相関 $(-0.55$ と -0.39$)$ が得られた。肉の 軟らかさと産肉形質との関連の報告は少ない。TEND についての高い遺伝率や産肉形質との高い遺伝相関か ら、本研究で肉の軟らかさを判定するために使ったテ ンシプレッサー（Nakai ら 1992）は肉の軟らかさの遺伝 的識別のためには優れた測定機器と判断される。IMF と TEND との遺伝と表型相関は -0.06 と -0.20 であり、 Sellier (1998) が報告しているようにIMF と TEND との 遺伝的関連は低いと言えよう。つまり、肉の軟らかさ は筋肉内脂肪含量に依存しているのではない。

豚の系統造成試験では無選抜の対照系を置いてい ない。毎年一定の時期に分婏、能力検定、選抜、交 配を行っており、能力検定での環境は各世代一定と 見なしてきた。そして世代を重複して雄豚を使用す るなど環境の影響を遺伝的評価から分離する方策を とって抢らず、選抜反応の正確な評価という点で問 題となると思われた。そこで、選抜形質及び相関形 質の選抜に伴う変化について、表型值と育種価の重 み付け累積選抜差を計算し、各形質の育種価の世代 変化を比較した。表 3 には表型值と育種価の重み付け 累積選抜差、遺伝率と選抜差から予測した期待選抜反 応および希望改良量を示した。DG、EMとBFの 6 世 代での重み付け累積選抜差はそれぞれ $225.07 \mathrm{~g}$ 、 $4.06 \mathrm{~cm}^{2}$ と $0.10 \mathrm{~cm}$ であり、これに遺伝率を乗じた予

表3. 選抜形質と相関形質の表型值及び育種価の重み付累積選抜差、期待選抜反応および希望改良量

\begin{tabular}{|c|c|c|c|c|c|}
\hline & $\begin{array}{c}\text { DG } \\
\mathrm{g}\end{array}$ & $\begin{array}{l}\mathrm{EM} \\
\mathrm{cm}^{2}\end{array}$ & $\begin{array}{l}\mathrm{BF} \\
\mathrm{cm}\end{array}$ & $\begin{array}{l}\mathrm{IMF} \\
\%\end{array}$ & $\begin{array}{r}\text { TEND } \\
\mathrm{kg} \mathrm{f} / \mathrm{cm}^{2}\end{array}$ \\
\hline $\begin{array}{c}\text { 表型值重み付累積選抜差 } \\
\text { (SD: G1-G6) }\end{array}$ & 225.07 & 4.06 & 0.10 & & \\
\hline $\begin{array}{c}\text { 遺伝率 } \\
\mathrm{h}^{2}\end{array}$ & 0.48 & 0.45 & 0.72 & 0.46 & 0.45 \\
\hline 期待反応: $\mathrm{SD} \times \mathrm{h}^{2}$ & 108.03 & 1.83 & 0.07 & & \\
\hline $\begin{array}{l}\text { 育種価の重み付累積選拢差 } \\
\text { (G1-G6) }\end{array}$ & 114.87 & 2.03 & 0.05 & 1.24 & -3.92 \\
\hline 第 7 世代の育種価 & 122.5 & 1.73 & 0.09 & 1.20 & -4.34 \\
\hline 希望改良量 & 135 & 3.9 & -0.54 & 0.70 & \\
\hline
\end{tabular}

DG：1 日平均増体量、 $\mathrm{EM}$ ：ロース断面積、 $\mathrm{BF}$ ：背脂肪厚、IMF：筋肉内脂肪、TEND：テンダーネス 
想選抜反応は $108.03 \mathrm{~g} 、 1.83 \mathrm{~cm}^{2}$ と $0.07 \mathrm{~cm}$ だった。一 方、6 世代での育種価の累積選抜差は $114.87 \mathrm{~g}$ 、 $2.03 \mathrm{~cm}^{2}$ と $0.05 \mathrm{~cm}$ であり、第 7 世代の DG、EM およ び BF の育種価の平均值は $122.5 \mathrm{~g} 、 1.73 \mathrm{~cm}^{2}$ および $0.09 \mathrm{~cm}$ だった。選抜差と遺伝率から推定した選抜反 応と育種価の平均值が大体一致していることから、 BLUP 法で推定した育種価の平均は選抜反応を反映し ていることが示唆された。また、IMFに関しては第 6 世代の育種価の重み付け選抜差と第 7 世代の育種価の 平均がそれぞれ $1.24 \%$ と $1.20 \%$ であり、IMFについ ても $1.2 \%$ 前後の選抜反応が得られた。さらに、 TEND は直接の選抜形質ではないが、第 4 世代以降の 選抜差が大きくなり、第 6 世代での育種価の累積選抜 差と第 7 世代の育種価平均はそれぞれ $-3.92 \mathrm{~kg} \mathrm{f} / \mathrm{cm}^{2}$ と $-4.34 \mathrm{~kg} \mathrm{f} / \mathrm{cm}^{2}$ となり、約 $4 \mathrm{~kg} \mathrm{f} / \mathrm{cm}^{2}$ 軟らかくなっ た。第 1 世代の能力から設定した改良目標量は DG、 EM、BF挍よびIMF がそれぞれ $135 \mathrm{~g} 、 3.9 \mathrm{~cm}^{2} 、$

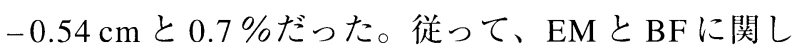
ては改良目標量を達成することは出来なかったが、 DGについてほぼ達成し、IMFについても目標量を上 回った。

このデユロック種の選抜に伴う繁殖成績の全体の世 代を通した平均分婏頭数、生産頭数、離乳頭数はそれ ぞれ 9.3 頭、 8.8 頭、7.4頭だった。また、第 7 世代の 近交係数、血縁係数はそれぞれ $8.03 \% 、 23.97 \%$ 、個 体間の最小血縁係数も $10 \%$ 以上となり、系統豚の認 定基準を満たした。さらに、米国 NPPC（1991）の 5 段 階を基準に第 7 世代の調査豚のマーブリングスコアを 判定した。その結果、4以上にランクされたものが去 勢と雌の合計全体の $87.7 \%$ \%めた。

以上、選抜の効果をみると 1 日平均増体量、ロース 断面積、背脂肪厚については、改良目標量を達成でき なかったが、筋肉内脂肪では目標量を上回った。第 7 世代の調查豚についてマーブリングスコアの 4 以上が 約 9 割を占めた。県内 100 世帯で試食モニタ一を実施 した結果、8 割が通常食べている豚肉より優れると評 価した。さらに、バークシャー純粋種やその交雑豚、 首都圈銘柄豚との肉質比較調查 (100 名の主婦) の結果 でも、デユロック種系統豚の豚肉の優位性を確認した (第6 世代 H 12)。また、卸売業者、小売り業者を対象 とした試食会でも絶讃の評価があり、仙台駅エスパル での試験販売でも好評だった(第 7 世代豚)。このデユ ロック種は現在、LWDの止雄として宮城県畜産試 験場から年間 6,000 本の精液と 100 頭以上の雄豚の供 給を行っている。同時に、純粋肉豚としての利用を考
え、平成 15 年度 2,000 頭、平成 16 年度には 3,500 頭、 平成 17 年度には 5,000 頭の純粋肉豚を目指す取り組み を開始しており、ほほ順調に進んでいる。

\section{3. 産肉形質と肉質形質を選抜形質としたデユロック 豚の肉質形質における相関反応}

デユロック種の選抜試験では筋肉内脂肪、軟らかさ の他にこれまで報告されている文献や既に肉質につい て詳しい調查を行ってきた国内の研究機関の情報を取 り入れ可能な限り多くの肉質に関する測定を行った。 肉色についてはと殺 24 時間後に採材したロース肉の 肉色標準模型 (PCS: Nakai 1975) と色差計による L* $a^{*} 、 b^{*}$ を測定した。また、 24 時間後の肉の $\mathrm{pH}$ も測定 した。保水性については、精肉と加熱した肉について 測定した。まず、精肉ではナイロンバック法を変形し た方法を採用した。これは、スライスした一定重量 (約 $50 \mathrm{~g}$ )のロース肉をふたにフックのついた標本ケー スにぶら下げ、 $4{ }^{\circ} \mathrm{C}$ の冷蔵庫で 24 時間、48 時間放置 し、この間の肉重量を測定してドリップロスとする方 法である。また、加熱した肉の保水性（加熱損失率あ るいはクッキングロス) は以下のような方法で測定し た。2胸椎分のロース肉を筋線維の方向に沿って 2 分 割しさらに、2 分割したそれぞれの部分から約 $2 \mathrm{~cm} \times$ $2 \mathrm{~cm} \times 5 \mathrm{~cm}$ の肉片を 1 つずつ採取した。正確に重量測 定後、ビニール袋に入れてパッキングした後、 $70{ }^{\circ} \mathrm{C}$ の 温浴で 30 分加熱し、その後 30 分冷水で冷ました後、 水を拭き取り重量を測定した。加熱前の重量に対する 重量損失の割合を計算した。この肉片をさらに厚さ $1 \mathrm{~cm}$ に整形してテンシプレッサーを使い、物理的特性 值 (tenderness、pliability など) を測定した。1つの肉片 について 5 カ所、従って一頭について 10 力所の測定 を平均した。

表 4 には肉質形質の遺伝率を示した。筋肉内脂肪と tenderness の遺伝率は中程度の值を示し、肉色 (PCS と $\mathrm{L}^{*}$ ) は低かった。保水性 (ドリップロス：DL と加熱損 失率：CL)の遺伝率も低く、 $\mathrm{pH}$ も 0.07 と低かった。 Sellier (1998) は、筋肉内脂肪は 0.5 前後、器械で測定 したTENDERNESS は 0.26、ドリップロスとクッキン グロスは 0.16 、肉色明るさは $0.28 、 \mathrm{pH}$ は 0.21 の遺伝 率を報告している。TENDERを除く本試験での值はほ とんどこの報告の值と同程度の遺伝率だった。さらに、 DLと PHについて、0.18 と 0.15 の比較的高い共通環 境効果の值が得られた。第 4 から 6 世代まで筋肉の電 気伝導度を示すインピーダンス値 (IMP) と総コラーゲ ン量 $(\mathrm{COL})$ について測定した。これらの遺伝率はそれ 
表 4. 選抜形質と肉質形質の基本統計量、遺伝率、共通環境効果および遺伝標準偏差

\begin{tabular}{|c|c|c|c|c|c|c|c|}
\hline \multicolumn{2}{|c|}{ Trait } & $\mathrm{n}$ & Mean & sd & $h^{2}(s e)$ & $\mathrm{c}^{2}(\mathrm{se})$ & $\sigma_{\mathrm{G}}$ \\
\hline DG & & 1642 & 873.6 & 109.3 & $0.47(0.02)$ & $0.04(0.01)$ & 55.3 \\
\hline EM & $\mathrm{cm}^{2}$ & 1639 & 37.0 & 4.0 & $0.45(0.02)$ & $0.02(0.01)$ & 2.5 \\
\hline $\mathrm{BF}$ & $\mathrm{cm}$ & 1642 & 2.37 & 0.43 & $0.72(0.02)$ & $0.02(0.01)$ & 0.33 \\
\hline IMF & $\%$ & 544 & 4.25 & 1.46 & $0.39(0.02)$ & $0.10(0.02)$ & 0.87 \\
\hline TEND & $\mathrm{kg} \mathrm{f} / \mathrm{cm}^{2}$ & 545 & 72.52 & 12.71 & $0.45(0.02)$ & $0.07(0.01)$ & 8.26 \\
\hline PCS & & 541 & 3.42 & 0.46 & $0.18(0.02)$ & $0.08(0.01)$ & 0.19 \\
\hline $\mathrm{L}$ & & 543 & 48.44 & 3.16 & $0.16(0.02)$ & $0.15(0.02)$ & 1.13 \\
\hline DL24 & $\%$ & 543 & 2.21 & 1.31 & $0.14(0.01)$ & $0.17(0.02)$ & 0.49 \\
\hline CL & $\%$ & 545 & 24.7 & 3.33 & $0.09(0.02)$ & $0.16(0.02)$ & 0.97 \\
\hline PH & & 515 & 5.97 & 0.43 & $0.07(0.02)$ & $0.22(0.02)$ & 0.07 \\
\hline IMP & $\Omega$ & 232 & 486.3 & 163.9 & $0.22(0.03)$ & $0.18(0.02)$ & 76.2 \\
\hline $\mathrm{COL}$ & $\%$ & 225 & 0.51 & 0.14 & $0.23(0.05)$ & $0.15(0.02)$ & 0.06 \\
\hline
\end{tabular}

表 5. 産肉形質と肉質形質間の遺伝相関 $\left(\mathbf{r}_{\mathbf{G}}\right.$ : カッコ内は標準誤差) と表型相関 $\left(\mathbf{r}_{\mathbf{P}}\right)$

\begin{tabular}{|c|c|c|c|c|}
\hline 形質 & & DG & EM & $\mathrm{BF}$ \\
\hline \multirow[t]{2}{*}{ IMF } & $\mathrm{r}_{\mathrm{G}}$ & $0.25(0.03)$ & $-0.26(0.04)$ & $0.28(0.03)$ \\
\hline & $\mathrm{r}_{\mathrm{P}}$ & 0.06 & -0.24 & 0.22 \\
\hline \multirow[t]{2}{*}{ TEND } & $\mathrm{r}_{\mathrm{G}}$ & $-0.44(0.03)$ & $0.32(0.04)$ & $-0.59(0.03)$ \\
\hline & $\mathrm{r}_{\mathrm{P}}$ & -0.34 & 0.19 & -0.39 \\
\hline \multirow[t]{2}{*}{ PCS } & $r_{G}$ & $-0.33(0.05)$ & $-0.08(0.06)$ & $-0.13(0.05)$ \\
\hline & $\mathrm{r}_{\mathrm{P}}$ & -0.16 & 0.04 & -0.13 \\
\hline \multirow[t]{2}{*}{$\mathrm{L}^{*}$} & $r_{G}$ & $0.33(0.05)$ & $-0.13(0.05)$ & $0.55(0.05)$ \\
\hline & $\mathrm{r}_{\mathrm{P}}$ & 0.20 & -0.11 & 0.23 \\
\hline \multirow[t]{2}{*}{ DL } & $r_{G}$ & $-0.14(0.05)$ & $0.64(0.05)$ & $-0.25(0.06)$ \\
\hline & $\mathrm{r}_{\mathrm{P}}$ & -0.05 & 0.07 & -0.08 \\
\hline \multirow[t]{2}{*}{$\mathrm{CL}$} & $\mathrm{r}_{\mathrm{G}}$ & $0.10(0.07)$ & $-0.01(0.08)$ & $-0.30(0.07)$ \\
\hline & $\mathrm{r}_{\mathrm{P}}$ & 0.07 & 0.00 & -0.04 \\
\hline \multirow[t]{2}{*}{$\mathrm{PH}$} & $\mathrm{r}_{\mathrm{G}}$ & $0.24(0.11)$ & $-0.40(0.12)$ & $0.47(0.10)$ \\
\hline & $r_{P}$ & 0.08 & -0.03 & -0.01 \\
\hline \multirow[t]{2}{*}{ IMP } & $r_{G}$ & $-0.28(0.05)$ & $-0.69(0.04)$ & $0.29(0.05)$ \\
\hline & $\mathrm{r}_{\mathrm{P}}$ & 0.05 & -0.15 & 0.04 \\
\hline \multirow[t]{2}{*}{$\mathrm{COL}$} & $r_{G}$ & $0.04(0.05)$ & $0.19(0.07)$ & $-0.35(0.07)$ \\
\hline & $\mathrm{r}_{\mathrm{P}}$ & 0.13 & 0.04 & -0.07 \\
\hline
\end{tabular}

IMF: 筋肉内脂肪, TEN: テンダーネス, PCS: 肉色標準模型、 L:明度, DL24：ドリップロス 24 時間後、CL : クッキングロス (加熱損失率)、 $\mathrm{PH}: \mathrm{pH}, \mathrm{IMF}$ : インピーダンス、COL: 総コ ラーゲン量 
ぞれ 0.22 と0.23の低い值を示した。

表 5 に産肉形質と肉質形質との遺伝と表型相関を示 した。DGはTEND と負の中程度の遺伝と表型相関を、 PCS と L*との間でも中程度の遺伝相関を示した。こ れらの結果から、増体量への改良は肉の軟らかさを増 し、肉色を淡くすることが示唆された。一方、DGと IMF との遺伝相関と表型相関は低かった。ロース断面 積はドリップロスと高い遺伝相関を示し、筋肉内脂肪 やTENDERNESS とも関連は弱いものの好ましくない 相関を示した。さらに、背脂肪厚は TENDERNESS や L 值とそれぞれ負と正の高い遺伝相関を示し、背脂肪 厚を薄く改良することが肉の硬さを増し、肉色を濃く することが示唆された。さらに、背脂肪厚と筋肉内脂 肪との遺伝と表型相関は 0.28 と 0.22 と低く、皮下へ の脂肪蓄積と筋肉内への脂肪の蓄積は関連が低いこと が示唆された。Sellier (1998) も両者の遺伝相関は 0.30 を超えず、筋肉内への脂肪蓄積の遺伝的変異は枝肉の 全体の脂肪蓄積に関する遺伝的変異と独立しているこ とを指摘している。IMP とロース断面積との間に負の 高い遺伝相関 (-0.69) が推定された。断面積の太い個 体から採材したロース肉は抵抗值 (レジスタンス) が小 さい。これは水分含量が高いためと思われる。

肉質形質間の遺伝、表型相関を表 6 に示した。食味
性に直接関連すると思われる IMF、TENDER と DL、 $\mathrm{CL}$ と肉質予測基準值となる形質 (肉色、 $\mathrm{pH} 、 \mathrm{IMP}$ と コラーゲンなど）との関連から、精肉と加熱肉の保水 性は筋肉内脂肪が増加すると改善されること、一方、 筋肉内脂肪と TENDの間の遺伝相関は -0.09 と低く関 連がないことが示唆された。

選抜に伴う肉質形質の育種価の推移を検討した結 果、選抜世代が進むにつれて IMF は増加し、肉色の L*が高くなった。一方、ドリップロスはわずかに減 少し、 $\mathrm{pH}$ はとんど変化しなかった。TENDは4 世代 以降 7 世代まで減少し、肉が軟らかくなったことが示 唆された。以上のことから、デユロック豚において、 増体量と筋肉内脂肪を選抜形質とした 7 世代の選抜の 結果、相関反応として肉が軟らかくなり、肉色が淡く なった。

\section{4. 選抜に伴う豚皮下脂肪の脂肪酸組成と融点、筋肉 内および筋肉間脂肪の肪酸組成の変化と遺伝的パ ラメータの推定}

脂肪酸組成を分析した材料の採材部位はいずれも最 期胸椎から 3 胸椎前の部分の皮下脂肪を含むロース部 位とした。皮下脂肪内層と外層、筋肉間脂肪と筋肉内 脂肪に分割し、脂肪酸組成はガスクロマトグラフィー

表 6. 肉質形質間の遺伝相関 (対角線上側; カッコ内は標準誤差) と表型相関 (対角線の下側)

\begin{tabular}{|c|c|c|c|c|c|c|c|c|c|}
\hline & IMF & TEN & PCS & $\mathrm{L}$ & $\mathrm{DL}$ & $\mathrm{CL}$ & $\mathrm{PH}$ & IMP & $\mathrm{COL}$ \\
\hline IMF & & $\begin{array}{c}-0.09 \\
(0.04)\end{array}$ & $\begin{array}{c}-0.05 \\
(0.06)\end{array}$ & $\begin{array}{c}0.42 \\
(0.05)\end{array}$ & $\begin{array}{c}-0.70 \\
(0.05)\end{array}$ & $\begin{array}{c}-0.42 \\
(0.09)\end{array}$ & $\begin{array}{c}-0.51 \\
(0.12)\end{array}$ & $\begin{array}{c}0.31 \\
(0.06)\end{array}$ & $\begin{array}{c}0.43 \\
(0.08)\end{array}$ \\
\hline TEN & -0.20 & & $\begin{array}{c}0.59 \\
(0.07)\end{array}$ & $\begin{array}{c}-0.59 \\
(0.08)\end{array}$ & $\begin{array}{c}0.04 \\
(0.06)\end{array}$ & $\begin{array}{c}0.24 \\
(0.07)\end{array}$ & $\begin{array}{c}-0.16 \\
(0.12)\end{array}$ & $\begin{array}{c}0.26 \\
(0.06)\end{array}$ & $\begin{array}{c}0.26 \\
(0.06)\end{array}$ \\
\hline PCS & -0.18 & 0.19 & & $\begin{array}{c}-0.81 \\
(0.04)\end{array}$ & $\begin{array}{c}-0.31 \\
(0.07)\end{array}$ & $\begin{array}{c}-0.13 \\
(0.09)\end{array}$ & $\begin{array}{c}0.16 \\
(0.11)\end{array}$ & $\begin{array}{c}0.68 \\
(0.05)\end{array}$ & $\begin{array}{c}0.29 \\
(0.09)\end{array}$ \\
\hline $\mathrm{L}$ & 0.43 & -0.24 & -0.50 & & $\begin{array}{c}0.06 \\
(0.07)\end{array}$ & $\begin{array}{c}-0.22 \\
(0.13)\end{array}$ & $\begin{array}{c}-0.10 \\
(0.12)\end{array}$ & $\begin{array}{c}-0.28 \\
(0.07)\end{array}$ & $\begin{array}{c}-0.17 \\
(0.10)\end{array}$ \\
\hline DL & -0.13 & 0.02 & -0.13 & 0.19 & & $\begin{array}{c}0.01 \\
(0.11)\end{array}$ & $\begin{array}{c}0.20 \\
(0.14)\end{array}$ & $\begin{array}{r}-0.60 \\
(0.07)\end{array}$ & $\begin{array}{c}-0.09 \\
(0.12)\end{array}$ \\
\hline $\mathrm{CL}$ & -0.07 & 0.19 & -0.20 & 0.25 & 0.35 & & $\begin{array}{c}0.21 \\
(0.17)\end{array}$ & $\begin{array}{c}-0.28 \\
(0.11)\end{array}$ & $\begin{array}{c}-0.64 \\
(0.08)\end{array}$ \\
\hline $\mathrm{PH}$ & -0.07 & -0.05 & 0.07 & -0.12 & -0.20 & 0.00 & & $\begin{array}{c}0.28 \\
(0.15)\end{array}$ & $\begin{array}{c}-0.42 \\
(0.20)\end{array}$ \\
\hline IMP & 0.07 & 0.01 & 0.20 & -0.12 & -0.44 & -0.30 & 0.05 & & $\begin{array}{c}0.20 \\
(0.13)\end{array}$ \\
\hline $\mathrm{COL}$ & 0.12 & 0.00 & -0.02 & 0.18 & 0.03 & 0.06 & 0.03 & 0.08 & \\
\hline
\end{tabular}

IMF: 筋肉内脂肪、TEN: テンダーネス、PCS: 肉色標準模型、L: 明度、DL24: ドリップロス 24 時間後、CL: クッ キングロス (加熱損失率)、PH: pH、IMF: インピーダンス、COL: 総コラーゲン量 
を使い測定した。

選抜に伴う皮下脂肪内層、外層の各脂肪酸組成の表 型值の変化をみると、飽和脂肪酸であるミリスチン酸

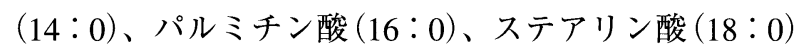
は有意に減少し、不飽和脂肪酸であるオレイン酸 (18：1）が有意に増加した。また、リノール酸は変化 が少なかった。さらに、内層及び外層の融点は世代が 進むと有意に低くなった。
表 7 に皮下脂肪内層、外層の融点と脂肪酸組成、筋 肉間と筋肉内脂肪の脂肪酸組成の平均值と遺伝率を示 した。ステアリン酸 $(\mathrm{C} 18 ： 0)$ が内層と外層でそれぞ れ 0.51 と 0.54 と最も高く、筋肉間脂肪と筋肉内脂肪 でも 0.51 と 0.40 の高い值が推定された。パルミチン 酸は筋肉間で 0.79 と高い遺伝率だったが、他の部位で は 0.30-0.50と中から高の值だった。パルミトレイン 酸 $(\mathrm{C} 16: 1)$ は $0.20-0.36$ 、オレイン酸 $(\mathrm{C} 18: 1)$ は

表 7. 皮下脂肪内層と外層、筋肉間と筋肉内脂肪の脂肪酸組成の基本統計量と遺伝率

\begin{tabular}{|c|c|c|c|c|c|c|}
\hline & & $\mathrm{N}$ & Mean & $\mathrm{SD}$ & 遺伝率 & 標準誤差 \\
\hline \multicolumn{7}{|l|}{ 皮下脂肪内層 } \\
\hline $\mathrm{C} 14: 0$ & $\%$ & 517 & 1.6 & 0.4 & 0.15 & 0.04 \\
\hline $\mathrm{C} 16: 0$ & $\%$ & 517 & 27.0 & 1.9 & 0.30 & 0.06 \\
\hline $\mathrm{C} 16: 1$ & $\%$ & 517 & 2.0 & 0.7 & 0.36 & 0.04 \\
\hline $\mathrm{C} 18: 0$ & $\%$ & 517 & 16.9 & 1.9 & 0.51 & 0.06 \\
\hline $\mathrm{C} 18: 1$ & $\%$ & 517 & 42.9 & 2.5 & 0.28 & 0.04 \\
\hline $\mathrm{C} 18: 2$ & $\%$ & 517 & 9.6 & 1.7 & 0.32 & 0.04 \\
\hline 融点 & ${ }^{\circ} \mathrm{C}$ & 509 & 39.4 & 3.0 & 0.61 & 0.08 \\
\hline \multicolumn{7}{|l|}{ 皮下脂肪外層 } \\
\hline $\mathrm{C} 14: 0$ & $\%$ & 515 & 1.6 & 0.4 & 0.07 & 0.03 \\
\hline $\mathrm{C} 16: 0$ & $\%$ & 515 & 25.3 & 2.1 & 0.50 & 0.06 \\
\hline $\mathrm{C} 16: 1$ & $\%$ & 515 & 2.8 & 0.8 & 0.20 & 0.04 \\
\hline $\mathrm{C} 18: 0$ & $\%$ & 515 & 13.9 & 1.7 & 0.54 & 0.04 \\
\hline $\mathrm{C} 18: 1$ & $\%$ & 515 & 45.8 & 2.5 & 0.26 & 0.04 \\
\hline $\mathrm{C} 18: 2$ & $\%$ & 515 & 10.6 & 1.7 & 0.44 & 0.04 \\
\hline 融点 & ${ }^{\circ} \mathrm{C}$ & 509 & 34.7 & 3.2 & 0.56 & 0.06 \\
\hline \multicolumn{7}{|l|}{ 筋肉間脂肪 } \\
\hline $\mathrm{C} 14: 0$ & $\%$ & 481 & 1.7 & 0.5 & 0.18 & 0.04 \\
\hline $\mathrm{C} 16: 0$ & $\%$ & 481 & 27.1 & 2.1 & 0.79 & 0.06 \\
\hline $\mathrm{C} 16: 1$ & $\%$ & 481 & 2.8 & 0.8 & 0.22 & 0.05 \\
\hline $\mathrm{C} 18: 0$ & $\%$ & 481 & 15.4 & 1.9 & 0.51 & 0.04 \\
\hline $\mathrm{C} 18: 1$ & $\%$ & 481 & 43.4 & 2.6 & 0.44 & 0.05 \\
\hline $\mathrm{C} 18: 2$ & $\%$ & 481 & 9.6 & 1.8 & 0.39 & 0.05 \\
\hline \multicolumn{7}{|l|}{ 筋肉内脂肪 } \\
\hline $\mathrm{C} 14: 0$ & $\%$ & 523 & 1.5 & 0.3 & 0.09 & 0.03 \\
\hline $\mathrm{C} 16: 0$ & $\%$ & 523 & 26.6 & 1.5 & 0.32 & 0.04 \\
\hline $\mathrm{C} 16: 1$ & $\%$ & 523 & 4.5 & 0.9 & 0.20 & 0.04 \\
\hline $\mathrm{C} 18: 0$ & $\%$ & 523 & 13.5 & 1.4 & 0.40 & 0.04 \\
\hline $\mathrm{C} 18: 1$ & $\%$ & 523 & 48.4 & 2.2 & 0.36 & 0.03 \\
\hline $\mathrm{C} 18: 2$ & $\%$ & 523 & 5.4 & 1.2 & 0.44 & 0.04 \\
\hline
\end{tabular}


0.26-0.44、リノール酸でも $0.32-0.44$ の遺伝率が推定 された。な挔、皮下脂肪内層と外層の融点の遺伝率は それぞれ 0.61 と 0.56 と高い值が推定された。豚脂肪 酸組成の遺伝的パラメー夕に関する報告は少なく、 Sellier (1998) は皮下脂肪のステアリン酸 $(\mathrm{C} 18 ： 0)$ で 0.51 、リノール酸 $(\mathrm{C} 18: 2)$ で 0.58 の遺伝率平均值を報 告している。また、Fernandezら (2003) は、筋肉内脂 肪の脂肪酸組成の遺伝率を推定し、最も高いのがステ アリン酸 $(\mathrm{C} 18 ： 0)$ の $0.41 、 \mathrm{C} 16: 0$ が 0.31 、オレイン 酸 $(\mathrm{C} 18: 1)$ が 0.31 、リノール酸 $(\mathrm{C} 18: 2)$ が 0.29 の遺 伝率を報告している。筋肉内脂肪の脂肪酸組成に及ぼ す遺伝的影響よりも給与される飼料内容の影響が大き い(Cameron ら 2000) ものの、脂肪酸組成の遺伝率は 中から高の遺伝率であると言える。

選抜形質である 4 形質と皮下脂肪内層と外層の脂肪 酸組成との遺伝相関、表型相関のうち皮下脂肪内層に ついてみると、飽和脂肪酸である $\mathrm{C} 16: 0$ と $\mathrm{C} 18 ： 0$ は $\mathrm{DG}(0.23 、 0.17$ と $0.36 、 0.22)$ と背脂肪厚 $(0.47 、 0.24$ と $0.47 、 0.24)$ との間で正の遺伝相関、表型相関を示 した。一方、ロース断面積とは負の遺伝相関 $(-0.20$ と $-0.44)$ と表型相関 $(-0.13$ と -0.20$)$ を示した。逆に C16：1 と C18：2 はDG と BF との間では比較的高い負 の遺伝相関と表型相関を示し、ロース断面積との間で は正の遺伝相関、表型相関を示した。C18：1はDG と $\mathrm{BF}$ との間に 0.1 以下の低い遺伝相関、表型相関を示し、 ロース断面積との間でも 0.20 の低い遺伝相関だった。 IMF は C14：0(-0.33) およびC18：1 (-0.17) と負の遺 伝相関を示したが、その他の脂肪酸組成とは 0.1 以下 の低い遺伝相関だった。

皮下脂肪外層の脂肪酸組成と産肉、肉質形質との関 連は内層と同じ傾向だが、全体として遺伝相関、表型 相関ともその絶対值が内層との相関より低かった。さ らに、外層融点との相関も内層融点と同様の傾向が見 られ、C18：0 と正の $\mathrm{C} 18 ： 1$ および $\mathrm{C} 16: 1$ と負の遺伝 相関と表型相関を示した。

筋肉間および筋肉内脂肪の脂肪酸組成と産肉、肉質 形質間の遺伝相関と表型相関について、飽和脂肪酸の C16：0 と C18：0 は DG、BF と正の遺伝相関と表型相 関を示し、EMと負の遺伝相関、表型相関を示した。 一価の不飽和脂肪酸である $\mathrm{C} 16: 1$ と多価不飽和脂肪 酸である $\mathrm{C} 18 ： 2$ は DG、BF と負の遺伝相関、表型相 関を示し、EMと正の遺伝相関、表型相関を示した。 そして、C18：1はDGとはゼロに近い負の相関だが、 BF とは正の遺伝と表型相関を、C16：1 と $\mathrm{C} 18 ： 2$ とは 負の遺伝と表型相関を示した。
以上のことから、増体の改良は飽和脂肪酸を増加さ せること、ロースの太さの増加と皮下脂肪厚の減少は 飽和脂肪酸を減少させ、多価不飽和脂肪酸を増加させ ることになることが示唆された。そして、筋肉内脂肪 酸組成は皮下脂肪内層脂肪酸組成とは必ずしも関連が 無いことが示された。さらに、融点は、C18：1 と負 の高い遺伝相関 $(-0.87)$ と表型相関 $(-0.40)$ を示し、 $\mathrm{C} 16 ： 1$ との遺伝相関 $(-0.64)$ も高かった。逆に C18：0 との間には高い正の遺伝相関 $(0.85)$ と表型相関 $(0.56)$ を示した。

バークシャー種純粋種とデユロック種第 6 世代を同 じ飼養条件下で肥育、と殺し、皮下脂肪内層、外層筋 肉内脂肪の脂肪酸組成を比較した。その結果、デユロ ック種はバークシャー種と比べ飽和脂肪酸が少なく、 C18：1のオレイン酸の割合が多かった。また、C18：2 と 18 : 3 の高度不飽和脂肪酸もデユロックが多いこ とが明らかとなった。その結果皮下脂肪内層、外層の 融点はいずれもデユロック種がバークシャー種より低 かった(Suzuki ら 2003)。

\section{5. 豚の血中 IGF-_およびレプチン濃度と産肉·肉質 形質との遺伝的関連}

a. 血中 IGF-1 濃度亡産肉 ·肉質形質亡の遺伝的関連 インスリン様成長因子 1（IGF-1）などの血液中の生 理活性物質は生きた動物から容易に採血できるので生 産形質の選拔指標として有用と思われる。さらに、若 齢時に測定した濃度が動物の将来の能力を予測できれ ば選抜にとって特に有用となる。IGF-1 は成長ホルモ ンの刺激を受け、おもに肝臓から分泌される。GH ホ ルモンは日内変動が大きいが、IGF-1 濃度は成長に伴 い安定して増加するので、遺伝的改良の生理的指標と しての有効性が指摘されている(Scanes ら 1987)。マ ウスについて、血中 IGF-1 に関して7 世代と 5 世代の 選抜実験から 0.15 と 0.10 の低い実現遺伝率が推定さ れている (Blairら 1989；Bakerら 1991)。これらの報 告では IGF-1 と体重の間に正の遺伝相関を報告してい る。一方、豚については Bunter ら (2002) が 0.20-0.58 の遺伝率と皮下脂肪厚㧍よび飼料転換効率との間に正 の遺伝相関を報告している。しかし、肉牛については IGF-1 と成長、皮下脂肪厚の間に負の遺伝相関の報告 がある (Davis と Simmen 1997; Davis と Simmen 2000)。 全体として産肉形質と IGF-1 との遺伝的関連について の報告は少ない。そこで、選抜の第 4 世代以降 IGF-1 を測定し、遺伝率と産肉形質との遺伝相関を推定する こと、IGF-1 が成長率に関する選抜の性的指標として 
有効かどうかを検討した。

選抜 4 世代以降、 8 週龄時と体重 $105 \mathrm{~kg}$ 時点で採血 し、遠心分離後血清を $-30{ }^{\circ} \mathrm{C}$ で凍結保存し、 IGF-1 結 合蛋白を除去後、二抗体 RIA 法により IGF-1 濃度測定 した。遺伝的パラメータはVCE4.25 (Neumaier と Groeneveld 1998）を使い、世代と性を母数効果、相加 的遺伝的効果と共通環境効果を変量とした多形質アニ マルモデル REML法により推定した。

表 8 には産肉形質と IGF-1 濃度の遺伝率を示した。 8 週齢時と $105 \mathrm{~kg}$ 体重時の IGF-1 濃度の遺伝率は 0.23 と 0.26 だった。また、 $105 \mathrm{~kg}$ 時と比べ 8 週齢時の IGF-
1 の共通環境効果は 0.20 と大きかった。 8 週齢時 IGF-1 濃度は 8 週齢時の体重とは中程度の遺伝相関だが、 DG、EM、BF、IMF、TENDERNESS との遺伝相関は 低かった。1 $05 \mathrm{~kg}$ 時の I G F - 1 濃度は EM、 TENDERNESS と中程度の遺伝相関を示したが、その 他の産肉形質との遺伝相関は低かった。 8 週齢時と $105 \mathrm{~kg}$ 時点の IGF-1 濃度の遺伝相関は高かったが、表 型相関は低かった (表 9)。

表 10 には第 4 世代から 7 世代までの 8 週齢と $105 \mathrm{~kg}$ 時点の IGF-1 濃度を性別に示した。 8 週齢時 IGF-1 濃 度は選抜が進むにつれて増加したが、7 世代では 8 週

表 8. 選抜形質、相関形質と IGF-1 濃度の基本統計量、遗伝率 $\left(\mathbf{h}^{2}\right)$ 、共通環境効果 $\left(\mathbf{c}^{2}\right)$ と表型標準偏差 $\left(\sigma_{\mathbf{p}}\right)$

\begin{tabular}{lrrrccc}
\hline \multicolumn{1}{c}{ 形 質 } & \multicolumn{1}{c}{$\mathrm{N}$} & Mean & $\mathrm{SD}$ & $\mathrm{h}^{2} \pm \mathrm{SE}$ & $\mathrm{c}^{2} \pm \mathrm{SE}$ & $\sigma_{\mathrm{p}}$ \\
\hline 1 日平均增体量, $\mathrm{g} / \mathrm{day}$ & 1,642 & 873.6 & 109.3 & $0.49 \pm 0.03$ & $0.04 \pm 0.01$ & 80.7 \\
ロース断面積, $\mathrm{cm}^{2}$ & 1,639 & 37.00 & 4.05 & $0.43 \pm 0.03$ & $0.02 \pm 0.01$ & 3.69 \\
背脂肪厚, $\mathrm{cm}$ & 1,642 & 2.37 & 0.43 & $0.73 \pm 0.02$ & $0.02 \pm 0.01$ & 0.39 \\
筋肉内脂肪, \% & 543 & 4.25 & 1.46 & $0.39 \pm 0.03$ & $0.08 \pm 0.02$ & 1.40 \\
テンダーネス, $\mathrm{kg} \mathrm{f} / \mathrm{cm}^{2}$ & 544 & 72.51 & 12.71 & $0.39 \pm 0.04$ & $0.08 \pm 0.02$ & 12.7 \\
8 週齢時体重, $\mathrm{kg}$ & 1,642 & 22.69 & 3.76 & $0.24 \pm 0.02$ & $0.36 \pm 0.03$ & 3.18 \\
8 週齢時背脂肪厚, $\mathrm{cm}$ & 1,639 & 1.02 & 0.20 & $0.41 \pm 0.02$ & $0.17 \pm 0.02$ & 1.66 \\
飼料要求率 & 379 & 2.65 & 0.17 & $0.35 \pm 0.04$ & $0.15 \pm 0.04$ & 0.17 \\
IGF1-8W ${ }^{\mathrm{a}}, \mathrm{ng} / \mathrm{ml}$ & 832 & 102.8 & 62.0 & $0.23 \pm 0.03$ & $0.20 \pm 0.02$ & 40.0 \\
IGF1-105KG, $\mathrm{ng} / \mathrm{ml}$ & 834 & 128.5 & 68.9 & $0.26 \pm 0.03$ & $0.03 \pm 0.01$ & 44.5 \\
\hline
\end{tabular}

a 8 週龄時 IGF- 1 濃度

${ }^{\mathrm{b}} 105 \mathrm{~kg}$ 時 IGF-1 濃度

表9. IGF-1 濃度と選拢形質相関形質の遺伝相関 $\left(\mathbf{r}_{\mathbf{G}}\right)$ と表型相関 $\left(\mathbf{r}_{\mathbf{P}}\right)$

\begin{tabular}{|c|c|c|c|c|}
\hline \multirow[b]{2}{*}{ 形 質 } & \multicolumn{2}{|c|}{ IGF1-8W ${ }^{a}$} & \multicolumn{2}{|c|}{ IGF1-105KG ${ }^{b}$} \\
\hline & $\mathrm{r}_{\mathrm{G}} \pm \mathrm{SE}$ & $r_{P}$ & $\mathrm{r}_{\mathrm{G}} \pm \mathrm{SE}$ & $\mathrm{r}_{\mathrm{P}}$ \\
\hline 1 日平均増体量 & $0.26 \pm 0.08$ & 0.08 & $0.22 \pm 0.07$ & 0.05 \\
\hline ロース断面積 & $0.22 \pm 0.10$ & 0.02 & $0.42 \pm 0.08$ & 0.19 \\
\hline 背脂肪厚 & $0.13 \pm 0.08$ & 0.10 & $-0.02 \pm 0.07$ & -0.11 \\
\hline 筋肉内脂肪 & $0.32 \pm 0.10$ & 0.04 & $0.26 \pm 0.09$ & -0.17 \\
\hline テンダーネス & $-0.05 \pm 0.12$ & 0.02 & $0.36 \pm 0.10$ & 0.30 \\
\hline 8 週龄時体重 & $0.45 \pm 0.08$ & 0.40 & $0.09 \pm 0.09$ & -0.08 \\
\hline 8 週歯令時背脂肪厚 & $0.33 \pm 0.06$ & 0.28 & $0.00 \pm 0.06$ & -0.09 \\
\hline 飼料要求率 & $0.20 \pm 0.08$ & 0.13 & $-0.17 \pm 0.07$ & -0.21 \\
\hline IGF-1 濃度 at 8 wk & & & $0.73 \pm 0.08$ & 0.15 \\
\hline
\end{tabular}

a 8 週齢時 IGF-1 濃度

${ }^{b} 105 \mathrm{~kg}$ 時 IGF-1 濃度 
表 10. 性間、成長ステージと選抜世代別 IGF-1 濃度の最小二乗平均値

\begin{tabular}{|c|c|c|c|c|c|c|}
\hline \multirow[b]{2}{*}{ 世 代 } & 形質 & \multicolumn{2}{|l|}{ IGF1-8W ${ }^{\mathrm{a}}, \mathrm{ng} / \mathrm{ml}$} & \multicolumn{3}{|c|}{ IGF1-105KG ${ }^{\mathrm{b}}, \mathrm{ng} / \mathrm{ml}$} \\
\hline & 雄 & 雌 & 去勢 c & 雄 & 雌 & 去勢 \\
\hline 4 & $45.4 \pm 6.2$ & $44.9 \pm 4.1$ & & $67.3 \pm 6.4^{f}$ & $49.8 \pm 4.7^{\mathrm{g}}$ & \\
\hline 5 & $104.7 \pm 5.7^{\mathrm{d}}$ & $75.3 \pm 3.7^{\mathrm{e}}$ & $90.1 \pm 5.5^{\mathrm{d}}$ & $159.3 \pm 6.0^{f}$ & $101.1 \pm 3.8^{\mathrm{g}}$ & $86.2 \pm 5.7^{\mathrm{h}}$ \\
\hline 6 & $158.9 \pm 5.9^{\mathrm{d}}$ & $129.3 \pm 3.6^{\mathrm{e}}$ & $133.6 \pm 5.6^{\mathrm{e}}$ & $184.4 \pm 5.9^{f}$ & $132.5 \pm 3.7 \mathrm{~g}$ & $98.2 \pm 5.7^{\mathrm{h}}$ \\
\hline 7 & $126.6 \pm 4.4^{\mathrm{d}}$ & $107.5 \pm 3.5^{\mathrm{e}}$ & $117.3 \pm 5.6^{\mathrm{de}}$ & $256.4 \pm 4.5^{f}$ & $146.4 \pm 3.5^{\mathrm{g}}$ & $116.2 \pm 5.7^{\mathrm{h}}$ \\
\hline
\end{tabular}

a 8 週齢時 IGF-1 濃度

${ }^{\mathrm{b}} 105 \mathrm{~kg}$ 時 IGF-1 濃度

cこれらの雄豚は採血後に全きょうだい検定用として去勢された。

d,e 同じ行の異なる上付き文字間で IGF1-8W について有意な性間差有り（P<0.05）

$\mathrm{f}, \mathrm{g}, \mathrm{h}$ 同じ行の異なる上付き文字間で IGF1-105KG について有意な性間差有り $(\mathrm{P}<0.05)$

齢体重が減少したためか IGF-1 濃度も下がった。雄、 雌共に 8 週歯時と比べ $105 \mathrm{~kg}$ 時点では IGF-1 濃度が増 加したが、去勢では変化せず、6世代では減少した。

Hermesch ら (2001) およびCameron ら (2003) は遺伝 率推定時における共通環境効果の影響を指摘したが、 本試験でも共通環境効果を考慮せず推定した 8 週齢時 の IGF-1 濃度の遺伝率は 0.37 と適度な值を示した。共 通環境効果を考慮した本試験や他の報告から判断され るIGF-1の遺伝率は低いと言える。IGF-1 と産肉能力と の遺伝相関から早期の判定に IGF-1 濃度は有効とは言 えないことが明かとなった。IGF-1 と IMF との間に適 度な遺伝相関が得られた。しかし、IGF-1 と肉質の遺 伝的関連についての報告はほとんどない。本研究では 筋肉内脂肪の比較的多いデユロック種について検討し た。従って、この点については筋肉内脂肪の少ない他 の品種について確認する必要がある。若い日齢である 8 週齢で測定した IGF-1 と EM およびTENDERNESS と の遺伝相関と比べ、より年取った日齢である $105 \mathrm{~kg}$ 時 点の IGF-1 濃度と EM および TENDERNESS との遺伝 相関は大きくなった。このことは、IGF-1 濃度が EM の太さや赤肉量の増加と関連することを示唆してい る。雄の血清 IGF-1 濃度は日齢が進むと雌や去勢より も増加量が大きい。このことは IGF-1 濃度の発現がホ ルモンにより調節され、日齢に依存することを示唆す る。Cameron ら (2003) も、6 週齢で測定したIGF-1 は 背脂肪厚や飼料要求率と正の相関を得たが、検定終了 の $90 \mathrm{~kg}$ 時点の IGF-1 濃度はこれらと負の相関を示す ことを報告している。

8 週齢時の IGF-1 濃度は筋肉内脂肪と正の遺伝相関 を示した。また、 $105 \mathrm{~kg}$ 時点の IGF-1 濃度はロース断 面積と適度な遺伝相関を示した。これらの結果は血清
表 11. レプチン濃度の遺伝率と選抜形質および相関形質 との遺伝相関、表型相関

\begin{tabular}{lcc}
\hline \multicolumn{1}{c}{ 形 質 } & 遺伝相関 & 表型相関 \\
\hline 日々平均増体量 & $-0.14 \pm 0.05$ & 0.08 \\
ロース断面積 & $-0.64 \pm 0.05$ & -0.32 \\
背脂肪厚 & $0.69 \pm 0.03$ & 0.51 \\
8 週齢時背脂肪厚 & $0.82 \pm 0.04$ & 0.26 \\
筋肉内脂肪 & $0.22 \pm 0.06$ & 0.24 \\
テンダーネス & $-0.06 \pm 0.05$ & -0.18 \\
1 日平均飼料摄-取量 & $0.32 \pm 0.06$ & 0.32 \\
- レプチンの遺伝率 & $0.65 \pm 0.04$ & \\
レプチン、共通環境効果 & $0.18 \pm 0.04$ & \\
\hline
\end{tabular}

中 IGF-1 濃度は成長や産肉形質と何らかの関連を持つ ことを示唆しており、豚の育種に際して将来の筋肉内 脂肪蓄積能力を成長の初期の段階で間接的に選抜する 基準として有効かも知れないことを示している (Suzuki ら 2004)。

\section{b. 血中レプチン濃度と産肉. 内質形質との遺伝的関連}

選抜第 5、6、7 世代の調查豚 226 頭について測定し たレプチン濃度と産肉、肉質形質間の関連を表 11 に 示した。体重 $105 \mathrm{~kg}$ 時点で採血し、遠心分離後血清を $-30{ }^{\circ} \mathrm{C}$ で凍結保存した。RIA 法により測定した血中レ プチン濃度について、VCE4.25 プログラム (Neumaier と Groeneveld 1998）を使い、共通環境効果と相加的遺 伝子効果を変量、選抜世代と性を母数としたモデルで 遺伝的パラメータを推定した。血中レプチン濃度の遺 伝率は $0.65 \pm 0.02$ と高く、共通環境効果による遺伝率 
も $0.18 \pm 0.04$ と比較的高かった。背脂肪厚との遺伝相 関 $(0.69 \pm 0.08)$ と表型相関 $(0.51)$ は高かったが、筋肉 内脂肪との遺伝相関は $0.22 \pm 0.06$ 、表型相関も 0.24 と 低く、血中レプチン濃度は体全体の脂肪蓄積量を反映 した。また、一日平均増体量との遺伝相関と表型相関 はそれぞれ、 $-0.14 \pm 0.05$ と 0.08 、ロース断面積との 遺伝相関、表型相関はそれぞれ、 $-0.64 \pm 0.05 、-0.32$ と推定された。レプチン濃度に関する遺伝的パラメー 夕推定の報告は無く、他品種でも本試験で得られた皮 下脂肪厚との遺伝的関連を調べる必要があると思われ る。

\section{6. 豚の筋肉内脂肪を選抜形質とした選抜に伴う Seam fat スコアの変化}

筋肉内脂肪 (IMF) を選抜形質の一つとして選抜を行 った場合、相関反応として筋肉間脂肪の増加が予想さ れる。一方、高生産性の観点からは赤肉生産効率の高 い種豚の改良が望まれている。これまで豚体の脂肪割 合を減らすため、背脂肪厚を選抜形質として改良が行 われてきた。しかし、筋肉内脂肪と赤肉割合との間に は負の遺伝相関があり（Sellier 1998）、美味しい豚肉を 作ることと赤肉生産効率の高い豚肉を作るための改良 目標は矛盾した関係になっている。ところで、脂肪の
蓄積部位を枝肉で見ると皮下脂肪、筋肉間脂肪、腹部 脂肪に分けられる。枝肉全体の脂肪割合と筋肉内脂肪 との関連は報告されているが、皮下脂肪、筋肉間脂肪 および腹部脂肪の蓄積量と筋肉内脂肪との関連を明ら かにした報告はない。この関連を明らかにするために は皮下脂肪、筋肉間脂肪及び腹部脂肪に脂肪蓄積を分 けて測定する必要がある。そこで、枝肉断面画像の筋 肉内脂肪と皮下と筋肉間及び腹部の脂肪蓄積につい て、画像解析装置を用いて測定しこれらの遺伝的関連 を検討した。また、第 5、6 胸椎間の断面について米 国 NPPCで発表されている Seam fat score（ロース部分 を取り巻いている筋肉間脂肪蓄積を 1-5 段階でスコア 一化したもの)により評価した。

第 1 から 6 世代まで 464 頭について筋肉内脂肪と Seam fat score との遺伝相関、表型相関を計算した結果、 $0.16 、 0.23$ と低いが正の相関であり、筋肉内脂肪の改 良の際に留意すべき点と思われた。

表 12 には体長 $1 / 2$ 部位で超音波探傷器で測定した背 脂肪厚およびロース筋肉内脂肪と第 $5 、 6$ 胸椎、体長 $1 / 2$ 部位䏡よび最後胸椎部位の切断面各脂肪面積割合 との間の遺伝相関、それらの形質の遺伝率を示した。 背脂肪厚および筋肉内脂肪含量の遺伝率はそれぞれ 0.69 と 0.57 であり比較的高い值だった。各胸椎の脂肪

表 12. 枝肉横切断面の各脂肪面積割合の遺伝率と皮下脂肪および筋肉内脂肪との遺伝相関

\begin{tabular}{|c|c|c|c|}
\hline \multicolumn{4}{|c|}{ 遺伝相関 } \\
\hline & 背脂肪厚 & 筋肉内脂肪 & $h^{2} \pm S E$ \\
\hline \multicolumn{4}{|l|}{ 第 5-6 胸椎 } \\
\hline 皮下脂肪面積割合 & $0.76 \pm 0.09$ & $-0.46 \pm 0.15$ & $0.58 \pm 0.09$ \\
\hline 笳肉間脂肪面積割合 & $0.22 \pm 0.09$ & $0.80 \pm 0.15$ & $0.54 \pm 0.12$ \\
\hline 全脂肪面積割合 & $0.89 \pm 0.07$ & $0.14 \pm 0.17$ & $0.38 \pm 0.10$ \\
\hline \multicolumn{4}{|l|}{ 体長 $1 / 2$ 部位 } \\
\hline 皮下脂肪面積割合 & $0.89 \pm 0.06$ & $-0.26 \pm 0.14$ & $0.56 \pm 0.11$ \\
\hline 筋肉間脂肪面積割合 & $0.45 \pm 0.18$ & $0.19 \pm 0.23$ & $0.42 \pm 0.14$ \\
\hline 腹部脂肪面積割合 & $0.32 \pm 0.27$ & $0.25 \pm 0.29$ & $0.19 \pm 0.12$ \\
\hline 全脂肪面積割合 & $0.83 \pm 0.06$ & $0.00 \pm 0.19$ & $0.54 \pm 0.11$ \\
\hline \multicolumn{4}{|l|}{ 最期胸椎部位 } \\
\hline 皮下脂肪面積割合 & $0.90 \pm 0.06$ & $0.14 \pm 0.15$ & $0.80 \pm 0.11$ \\
\hline 筋肉間脂肪面積割合 & $0.68 \pm 0.64$ & $0.59 \pm 0.74$ & $0.01 \pm 0.02$ \\
\hline 腹部脂肪面積割合 & $0.09 \pm 0.19$ & $-0.09 \pm 0.22$ & $0.41 \pm 0.12$ \\
\hline 全脂肪面積割合 & $0.86 \pm 0.08$ & $0.10 \pm 0.21$ & $\begin{array}{r}0.39 \pm 0.10 \\
------~\end{array}$ \\
\hline $\mathrm{h}^{2} \pm \mathrm{SE}$ & $0.69 \pm 0.10$ & $0.57 \pm 0.12$ & \\
\hline
\end{tabular}


面積割合についてみると皮下脂肪面積割合はどの部位 でも高い遺伝率であり特に、最後胸椎部位の遺伝率は 0.80 と最も高かった。次に生体で測定した背脂肪厚と 各脂肪面積割合との遺伝相関をみると、皮下脂肪面積 および全脂肪面積の割合はどの部位でも高い遺伝相関 だった。すなわち、第 5、6 胸椎間部位では 0.76 と 0.89 、体長 $1 / 2$ 部位では 0.89 と 0.83 、最後胸椎部位で は 0.90 と0.86、そして、遺伝相関の標準䛊差も低く、 信頼性のある值であることが示された。このように、 超音波を使い生体で測定している背脂肪厚測定値は皮 下に蓄積した脂肪量を推定する上で精度も高い測定値 と言える。しかし、筋肉間や腹部脂肪面積割合との遺 伝相関は中程度でありこれらの脂肪蓄積を推定するた めには他の手法を使う必要があると思われる。

筋肉内脂肪と各切断面脂肪面積割合との遺伝相関は 切断面の部位や脂肪蓄積の種類が異なると相関の程度 が異なった。まず、皮下脂肪面積割合との相関では第 5、6 胸椎間部位、体長 $1 / 2$ 部位および最後胸椎部位で それぞれ、 $-0.46 、-0.26$ および 0.14 の遺伝相関だった。 このことから体の前半部分の皮下に脂肪を蓄積する個 体は筋肉内に脂肪を蓄積しない傾向にあると言える。 逆に、第 5、6 胸椎間の筋肉間脂肪面積割合と筋肉内 脂肪との遺伝相関は 0.80 と高い值だった。しかし、体 長 $1 / 2$ 部位および最後胸椎部位の筋肉間脂肪面積割合 との遺伝相関は 0.19 および 0.59 だった。最後胸椎部 位の筋肉間脂肪面積割合との遺伝相関は標準誤差が 0.73 と非常に大きく信頼性に欠ける。また、腹部脂肪 面積割合との遺伝相関も体長 $1 / 2$ 部位および最後胸椎 部位でそれぞれ 0.25 および-0.09 といずれも低い相関 だった。さらに、全脂肪面積割合との遺伝相関は第 $5 、$ 6 胸椎間部位、体長 $1 / 2$ 部位拉よび最後胸椎部位でそ れぞれ $0.14 、 0.00$ および 0.10 といずれも低い相関だっ た。これらのことから筋肉内脂肪含量の高い個体は体 の前半部分の筋肉間に脂肪を蓄積し、皮下には脂肪を 蓄積しない個体である可能性が高いことが示唆され た。しかし、筋肉内脂肪と第 $5 、 6$ 胸椎間切断面の皮 下脂肪㧍よび筋肉間脂肪面積の表型相関は 0.02 と 0.36 であり、筋肉間脂肪面積については遺伝相関も同様の 傾向だが、皮下脂肪面積割合については遺伝相関と表 型相関が異なる傾向が示された。

以上、背脂肪厚と各切断面皮下脂肪や全脂肪面積割 合との遺伝相関はいずれも高く、背脂肪厚が枝肉全体 の脂肪蓄積を推定する上で有効な形質であることが示 唆された。また、ロース筋肉内脂肪含量と枝肉切断面 各脂肪面積割合との遺伝相関から、枝肉前半部分の筋
肉内脂肪面積割合が筋肉内脂肪含量を推定する上で重 要な形質であることが示唆された。本試験では 158 頭 についての分析を行ったが、さらに例数を増やして分 析し、今回の分析で得られた結果を確認する必要があ ると思われた。

\section{7. 豚の系統造成の課題}

豚の系統造成試験は、各県、改良センターや全農が 養豚産業に利用される種豚の造成を第一の目的として いる。この試験は労力的にも大変な作業だが、人件費 を含む資金面でも多額の経費を要する。反面、周到に 準備された計画をこの試験に設定できれば得られる成 果は他県の系統造成はもとより、育種企業にとっても 参考になる情報が得られると思われる。1999 年にエジ ンバラ、ロスリン研究所のキャメロン博士を宮城県に 招聘しロスリン研究所での豚に選抜試験のねらいにつ いて質問した際、得られた成果をイギリスの育種会社 に提供すること、その見返りとして資金を提供しても らうことを聞いた。系統造成試験を種畜の造成ととも に、育種改良上の諸課題を解決するための試験研究と しても位置づけるべきだろう。

宮城県でのデユロック種の系統造成試験では未解決

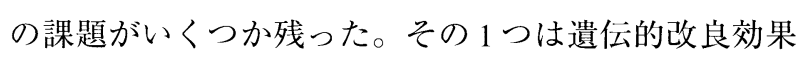
の判定方法である。系統造成では施設の収容能力に限 界があるため、無選抜の対照系を設定できない。 BLUP 法で育種価を推定する際、選抜世代を母数効果 として設定しているが、世代を重複して数頭の雄豚を 使うなど選抜世代と環境効果を分離して選抜の効果を 判定することも検討すべきだろう。また、正確な能力 測定に基づき表型值の選抜を行えば遺伝的改良は可能 だが、その生理的背景は不明なままの場合が多い。例 えば、肉の軟らかさとコラーゲンや筋線維型等との関 連、筋肉内脂肪蓄積のメカニズムなど他分野の研究者 との共同による生理的背景の原因解明が必要と思われ る。肉質形質の測定は煩雑であり、環境条件にも影響 される。相関の高い生理的指標や、 $r y r l$ 遺伝子や $R N$ 遺伝子のような DNA マーカーを指標とした選拔法が 今後も期待される。いくつかの県の系統造成ではこれ までも大学や他研究機関との共同研究を行っている。 今後はますます、そうした研究体制が望まれる。

\section{謝 辞}

本試験の大部分は宮城県畜産試験場で行なわれた が、著者らの他に清水ゆう子、鹿野裕志 (いずれも現 宮城県畜産試験場)、日野正浩 (宮城県畜産課)の各氏 
が造成の途中に関与した。本稿で紹介した研究成果の うち、脂肪組織の脂肪酸組成は宮城県農業短期大学の 石田光晴博士、IGF-1 濃度の測定やレプチン測定は東 北大学の加藤和雄博士と大学院生の中川一輝氏 (現味 の素)、肉のコラーゲン量は旧大阪府農林技術センタ 一の入江正和博士 (現宮崎大学農学部) との共同研究 により得られたものである。さらに、紙面の都合で紹 介できなかったが、上述した内容の他に、東北大学の 西田朗教授には抗病性形質の調査、山口高弘教授には 筋肉線維特性の調查、家畜改良センターの小林栄治博 士には肉質の DNA マーカーとの関連解析、新潟大学 の楠原征治教授と杉山稔恵博士には約 500 頭の肢蹄の 骨軟骨病変の調査を共同研究として取り組んだことを 付す。

\section{引用文献}

Baker RL, Peterson AJ, Bass JJ, Amyes N, Breier NC, Gluckman NC. 1991. Replicated selection for insulinlike growth factor-1 and body weight in mice. Theor. Appl. Genet., 81: 685-692.

Blair HT, McCutcheon SN, Mackenzie DS, Gluckman PD, Ormsby JE, Brier BH. 1989. Responses to divergent selection for plasma concentrations of insulin-like growth factor-1 in mice. Genet. Res., Camb., 53: $187-191$.

Bunter K, Hermesch S, Luxford BG, Lahti K, Sutcliffe E. 2002. IGF-1 concentration measured in juvenile pigs provides information for breeding programs: a mini review. Proc. 7th World Cong. Genet. Appl. Livest. Prod., Montpellier, France Communication No. 03-09.

Cameron ND. 1993. Selection for meat quality: objectives and criteria. Pig News Info., 14: 161N-168N.

Cameron ND, Enser M, Nute GR, Whittington FM, Penman JC, Fisken AC, Perry AM, Wood JD. 2000. Genotype with nutrition interaction on fatty acid composition of intramuscular fat and the relationship with fllavour of pig meat. Meat Science., 55: 187-195.

Cameron ND, McCullough E, Troup K, Penman C. 2003. Serum insulin-like growth factor- 1 concentration in pigs divergently selelcted for daily food intake or lean growth rate. J. Anim. Breed. Genet., 120: 1-10.

Clutter AC, Brascamp EW. 1998. Genetics of performance traits. In: Rothschild M F, Ruvinsky A. (Eds.), The Genetics of Pigs. CAB International, New York, pp. $427-462$.
Davis ME, Simmen RCM. 1997. Genetic parameter estimates for serum insulin-like growth factor 1 concentration and performance traits in Angus beef cattle. J. Anim. Sci., 75: 317-324.

Davis ME, Simmen RCM. 2000. Genetic parameter estimates for serum insulin-like growth factor 1 concentration and carcass traits in Angus beef cattle. J. Anim. Sci. 78: 2305-2313.

de Vries AG, van der Wal PG, Long T, Eikelenboom G, Merks JWM. 1994. Genetic parameters of pork quality and production traits in Yorkshire populations. Livest. Prod. Sci., 40: 277-289.

Fernandez A, de Pedro E, Nunez N, Silio L, Garcia-Casco J, Rodriguez C. 2003. Genetic parameters for meat and fat quality and carcass composition traits in Iberian pigs. Meat Sci. 64: 405-410.

Hermesch S, Luxford B G, Graser HU. 2000. Genetic parameters for lean meat yield, meat quality, reproduction and feed efficiency traits for Australian pigs. 2. Genetic relationships between production, carcass and meat quality traits. Livest. Prod. Sci., 65: $249-259$.

Hermesch S, Bunter KL, Luxford BG. 2001. Estimates of genetic correlations between IGF-1 recorded at $4 \mathrm{wk}$ of age and individual piglet weights at birth and 14 days, along with lifetime growth rate and backfat. Proc. Assoc. Advan. Anim. Breed. Genet. Queenstown, New Zealand, 14: 227-230.

Hovenier R, Kanis E, van Asseldonk Th, Westerink NG. 1992. Genetic parameters of pig meat quality traits in a halothane negative population. Livest. Prod. Sci., 32: $309-321$.

Hovenier R, Kanis E, van Asseldonk Th, Westerink NG. 1993. Breeding for pig meat quality in halothane negative populations - a review. Pig News Info., 14: $17 \mathrm{~N}-25 \mathrm{~N}$.

Kuhlers DL, Nadarajah K, Jungst SB, Anderson BL. 2001. Genetic selection for real-time ultrasound loin eye area in a closed line of Landrace pigs. Livest. Prod. Sci., 72: $225-231$.

Kuhlers DL, Nadarajah K, Jungst SB, Anderson BL, Gamble BE. 2003. Genetic selection for lean feed conversion in a closed line of Duroc pigs. Livest. Prod. Sci., 84: 75-82.

Lo LL, McLaren DG, McKeith FK, Fernando RL, 
Novakofski J. 1992. Genetic analyses of growth, realtime ultrasound, carcass and pork quality traits in Duroc and Landrace pigs. II Heritabilities and correlations. J. Anim. Sci., 70: 2387-2396.

Nakai H, Saito F, Ikeda T, Ando S, Komatsu A. 1975. Standard models of pork colour. Bull. Nat. Inst. Animal Industry, 29: 69-74.

Nakai H, Tanabe R, Ikeda T, Nishizawa M. 1992. Development of a technique for measuring tenderness in meat using a "Tensipresser". In Proceedings 38th International Congress of Meat Science and Technology, pp 947-950. 23-28 August

National Pork Producers Council. 1991. Procedures to evaluate market hogs, third edition. Des Moines: NPPC.

Neumaier A, Groeneveld E. 1998. Restricted maximum likelihood estimation of covariances in sparse linear models. Genet. Sel. Evol., 30: 3-26.

PEST. 1990. PEST User's Manual. Eildert Groeneveld Institute of Animal Husbandry and Animal Behaviour, FAL, Germany.
Scanes CG, Lazarus D, Bowen S, Buonomo FC, Gilbreath RL. 1987. Postnatal changes in circulating concentrations of growth hormone, somatomedin $\mathrm{C}$ and thyroid hormones in pigs. Domest. Anim. Endocrinol., 4: $253-257$.

Sellier P. 1998. Genetics of meat and carcass traits. In: Rothschild MF, Ruvinsky A. (Eds.), The Genetics of Pigs. CAB International, New York, pp. 463-510.

Sonesson AK, de Greef KH, Meuwissen THE. 1998. Genetic parameters and trends of meat quality, carcass composition and performance traits in two selected lines of large white pigs. Livest. Prod. Sci., 57: 23-32. Suzuki K, Shibata T, Kadowaki H, Abe H, Toyoshima T. 2003. Meat quality comparison of Berkshire, Duroc and crossbred pigs sired by Berkshire and Duroc. Meat Sci., 64: 35-42.

Suzuki K, Nakagawa K, Katoh K, Kadowaki H, Shibata T, Uchida H, Obara Y, Nishida A. 2004. Genetic correlation between serum insulin-like growth factor-1 concentration and performance and meat quality traits in Duroc pigs. J. Anim. Sci., 82: 994-999. 